\title{
Nutrient Uptake and Solute Movement in Drip Irrigated Summer Peppers ${ }^{1,2}$
}

\author{
C. L. Santiago and M. R. Goyal ${ }^{3}$
}

\begin{abstract}
A study on nutrient uptake ( $N, P, K, C a$ and $M g$ ) by peppers (var. Cubanelle) and fertilizer solute movement in relation to dripper location was conducted in the semiarid southern coast of Puerto Rico at the Fortuna Agricultural Research and Development Center. Soil samples were taken 9, 64, and 118 days after transplanting from each location, with three $15-\mathrm{cm}$ depth increments and three $15-\mathrm{cm}$ horizontal increments away from the dripper. These samples were analyzed for $\mathrm{pH}, \mathrm{EC}, \mathrm{P}, \mathrm{K}, \mathrm{Ca}$, and $\mathrm{Mg}$. All fertilizer was applied via drip irrigation. Factorial analysis indicated that solute movements at different positions were not statistically different. The relationships between nutrient uptake versus days after transplanting were of Mitscherlich's curve type. Greatest amount of nutrient uptake occurred during the last third part of the growing season, and followed an order of $\mathrm{K}>\mathrm{N}>\mathrm{Ca}>\mathrm{P}>\mathrm{Mg}$.
\end{abstract}

\section{INTRODUCTION}

Fertigation ${ }^{4}$ requires the knowledge of solute movement in the soil in relation to dripper location and nutrient uptake by plants during the crop season. It is difficult to modify the soil's physical properties and conditions which affect the moisture movement through the soil, yet operators can have an adequate control over the external factors such as dripper discharge and location, irrigation frequency and the nutrient source, all of which influence the growth characteristics of a plant.

Keng $(6,7)$ found limited movement of $\mathrm{P}$ and $\mathrm{K}$ in an Oxisol in Isabela. Goyal et al. (4) reported considerable movement of $\mathrm{P}$ in a Vertisol in Santa Isabel in a drip irrigated tomato field. Data on nutrient uptake and solute movement in trickle irrigated peppers is limited for southeast of Puerto Rico.

Drip irrigation calls for a complete fertigation schedule, thus providing adequate nutrients to the plant (3,10 to 13). The application of soluble fertilizers in low concentrations satisfies the plant requirement at different stages of growth resulting in increased fertilizer-use efficiency (11,

${ }^{1}$ Manuscript submitted to Editorial Board December 21, 1983.

${ }^{2}$ This study was conducted under Southeast Regional Project S-143 (H-326), "Trickle Irrigation in Humid Regions-Puerto Rico". This contribution is partly based on a MS thesis submitted by the Senior author in the Graduate School of the University of Puerto Rico, Mayagüez Campus, in partial fulfillment of the requirements for the degree of Master in Science in the Faculty of Agronomy and Soils-1983.

${ }^{3}$ Research Assistant and Associate Agricultural Engineer, Agricultural Experiment Station, University of Puerto Rico, Mayagüez Campus, Río Piedras. P. R. The authors thank Víctor A. Snyder, R. Caudales, Héctor Lugo-Mercado and J. Beaver for their valuable suggestions.

${ }^{4}$ Fertigation is the application of soluble fertilizers via irrigation systems. 
12, 13). Fertilizer applied via drip irrigation must be soluble to avoid precipitation in drip lines and clogging of drip lines. Rolston and Broadbent (15) indicated that volatilization of ammonia was minimum when ammonium sulphate was broadcast on a Panoche clay loam. Goldberg et al. (3) found that nitrate applied via drip irrigation was within the wetting pattern around the root system of the plant. Bar-Yosef and Shiekhoslan (1) observed that the nitrate loss was not significant in a sandy soil when applied via drip irrigation. Kafkafi and Bar-Yosef (5) observed high nitrate concentrations $(100 \mathrm{p} / \mathrm{m})$ at 20 and $40 \mathrm{~cm}$ away from the dripper source in a highly calcareous soil. The $\mathrm{P}$ was within $20 \mathrm{~cm}$ of the source. Potassium was distributed more uniformly than phosphorus in the wetted zone. Goldberg et al. (3) indicated movement of P vertically and horizontally $20 \mathrm{~cm}$ away from the dripper in a sandy loam when inorganic $\mathrm{P}$ at the rate of $20 \mathrm{~kg} / \mathrm{ha}$ was fertigated. Rauschkolb et al. (14) showed movement of orthophosphate away from the dripper location when applied via drip irrigation compared to that of banded applications in a Panoche clayey loam. They theorized that $\mathrm{P}$ movement was by mass flow in a saturated soil zone. Keng (6) found that P movement coincided with moisture movement in a sandy Bayamón soil, but it was limited in a clayey Coto soil. K movement was significant. Uriu et al. (16) observed considerable $\mathrm{K}$ movement away from the dripper location. Lorenz and Maynard (8) found that uptake of N, P and K by peppers was 157.2, 13.5 and $157.2 \mathrm{~kg} / \mathrm{ha}$, respectively. Biggest uptake occurred during be part of crop development.

A preliminary field study on nutrient uptake $(\mathrm{N}, \mathrm{P}, \mathrm{K}, \mathrm{Ca}$. wy peppers and fertilizer solute movement was conducted at Fortuna Agricultural Research and Development Center located in the semiarid southern coast of Puerto Rico. The soil belongs to the San Antón series, with a $\mathrm{pH}$ of 7.9. The conductivity of the soil solution is $0.21 \mathrm{mmhos}$ per $\mathrm{cm}$. Chemical analysis of the soil (2) indicated $22 \mathrm{meq} / 100 \mathrm{~g}$ of cation exchange capacity, $1.71 \mathrm{p} / \mathrm{m}$ of $\mathrm{P}, 694.4 \mathrm{p} / \mathrm{m}$ of $\mathrm{K}, 494.4 \mathrm{p} / \mathrm{m}$ of $\mathrm{Mg}$, and $5386 \mathrm{p} / \mathrm{m}$ of $\mathrm{Ca}$.

\section{MATERIALS AND METHODS}

Four-week-old pepper transplants (var. Cubanelle) were planted March $17,1982,15 \mathrm{~cm}$ from the dual chamber drip line and on both sides of the drip line at $30 \mathrm{~cm}$ spacing within the row. The treatments included white plastic and black plastic covers replicated four times. Two plants randomly chosen from each plot were cut at the soil surface and were ovendried for 48 hours at $70^{\circ} \mathrm{C}$. Dry samples were chopped and ground, and analyzed for $\mathrm{N}, \mathrm{P}, \mathrm{K}, \mathrm{Ca}$, and $\mathrm{Mg}$. Nitrogen was determined by the Kjeldahl macromethod; $\mathrm{P}$ by the $\mathrm{L}$-ascorbic acid $+\mathrm{NH}_{4} \mathrm{Mo}+\mathrm{H}_{2} \mathrm{SO}_{4}+$ antimony potassium tartrate method; and $\mathrm{K}, \mathrm{Ca}$, and $\mathrm{Mg}$ by the dry ash method (2). 
Nine soil samples were taken at 9,64 , and 118 days after transplanting from each location with a $3 \times 3$ grid pattern, three $15 \mathrm{~cm}$ depth increments, and three $15 \mathrm{~cm}$ horizontal increments directly below and horizontally perpendicular to an emitter, respectively. Each soil sample was air-dried and analyzed for $\mathrm{pH}$, electrical conductivity of a $2: 1$ water-soil extract ratio (which was then multipled by 2 to estimate the conductivity of the saturation extract), bicarbonate-extractable $\mathrm{P}$ (Olsen method), and $(1 N, \mathrm{pH}$ 7.00) ammonium acetate extractable $\mathrm{Ca}, \mathrm{Mg}$, and $\mathrm{K}$. Samples were analyzed at the Commonwealth Department of Agriculture Laboratory, Dorado, Puerto Rico.

\section{RESULTS AND DISCUSSION}

Table 1 indicates $\mathrm{N}, \mathrm{P}, \mathrm{K}, \mathrm{Ca}, \mathrm{Mg}$ uptake versus days after transplanting relationships for drip irrigated summer peppers in white plastic and black plastic mulched plots. Figure 1 shows a typical nutrient uptake curve. The relationships were of Mitscherlich type and exhibited the five nutrient uptake phases, namely a lag phase (plants are being established), a log phase (nutrient uptake continues), a decreasing phase (nutrient

TABLE 1.-Nutrient uptake by drip-irrigated summer pepper plants

\begin{tabular}{|c|c|c|c|c|c|}
\hline \multirow{2}{*}{ Treatment $^{1}$} & \multirow{2}{*}{ Parameter } & \multicolumn{3}{|c|}{ Regression coefficients ${ }^{2}$} & \multirow{2}{*}{$\begin{array}{l}\text { Coefficient of } \\
\text { determination, } R^{2}\end{array}$} \\
\hline & & A & $\mathrm{B}$ & $\mathrm{C}$ & \\
\hline \multicolumn{6}{|c|}{ Pepper leaves and branches } \\
\hline \multirow[t]{5}{*}{$\mathrm{T} 2$} & Nitrogen & 1.210 & 21.870 & 0.0430 & 0.95 \\
\hline & Potassium & 2.065 & 26.350 & 0.0456 & 0.95 \\
\hline & Phosphorus & 0.197 & 42.505 & 0.0511 & 0.98 \\
\hline & Calcium & 1.150 & 32.140 & 0.0389 & 0.97 \\
\hline & Magnesium & 0.185 & 32.093 & 0.0550 & 0.97 \\
\hline \multirow[t]{5}{*}{$\mathrm{T} 3$} & Nitrogen & 1.550 & 117.660 & 0.062 & 0.93 \\
\hline & Potassium & 2.360 & 138.820 & 0.066 & 0.96 \\
\hline & Phosphorus & 0.243 & 658.210 & 0.086 & 0.97 \\
\hline & Calcium & 0.920 & 493.470 & 0.087 & 0.94 \\
\hline & Magnesium & 0.228 & 171.630 & 0.073 & 0.93 \\
\hline \multicolumn{6}{|c|}{ Pepper fruits } \\
\hline \multirow[t]{3}{*}{$\mathrm{T} 2$} & Nitrogen & 1.360 & 22.960 & 0.0370 & 0.78 \\
\hline & Potassium & 1.220 & 17.530 & 0.0390 & 0.76 \\
\hline & Phosphorus & 0.410 & 32.240 & 0.0430 & 0.77 \\
\hline \multirow[t]{3}{*}{ T3 } & Nitrogen & 1.910 & 58.779 & 0.0380 & 0.96 \\
\hline & Potassium & 3.210 & 54.349 & 0.0309 & 0.95 \\
\hline & Phosphorus & 1.005 & 116.360 & 0.0299 & 0.97 \\
\hline
\end{tabular}

${ }^{1} \mathrm{~T} 2=$ White plastic mulch, $\mathrm{T} 3=$ Black plastic mulch.

${ }^{2}$ Nutrient uptake relationship (Mitscherlich's curve type): $\mathrm{Y}_{1,2}=\mathrm{A} /\left(1+\mathrm{Be}^{-\mathrm{cx}}\right)$, where $Y_{1}=$ Nutrient uptake for leaves and plants, g/plant;

$\mathrm{Y}_{2}=$ Nutrient uptake by fruits, g/fruit;

$\mathrm{Y}=$ Total nutrient uptake, $\mathrm{g} / \mathrm{plant}$;

$\mathrm{X}=$ Days after transplanting;

$\mathrm{A}, \mathrm{B}, \mathrm{C}=$ Regression coefficients. 


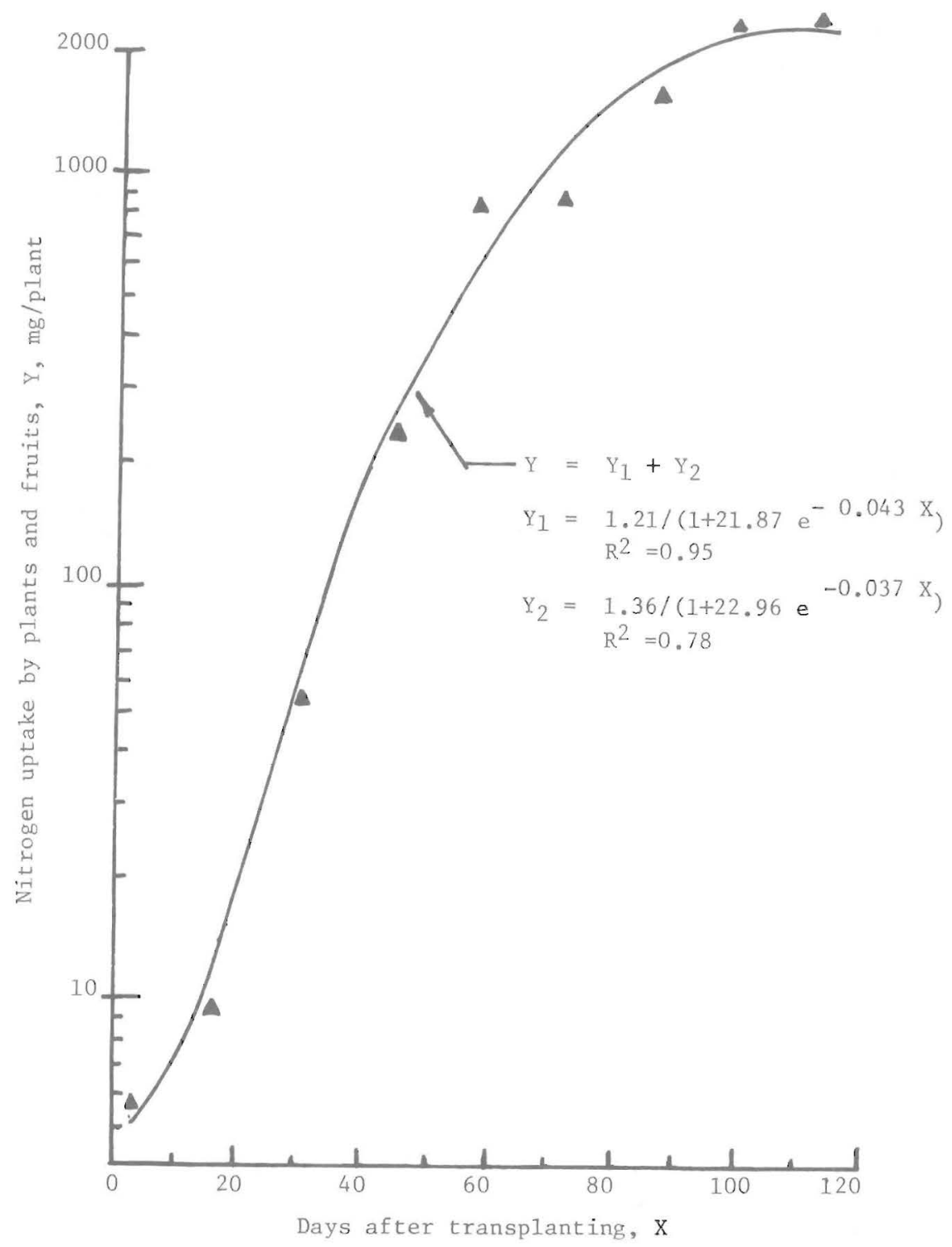

FIG, 1.-Nitrogen uptake by drip-irrigated pepper plants in white plastic mulched plots. Each data point is a mean of four observations.

uptake rate is decreasing, but plant still continues to extract the nutrient), a point at which nutrient uptake is maximum, and a senescence phase. Table 1 shows the values of regression coefficients (A, B, C) and coefficient of determination $\left(R^{2}\right)$. The regression coefficients were significant 
at the $5 \%$ level. The nutrient uptake values on days of observation were not statistically different at $5 \%$ in the white plastic and black plastic mulched plots.

The greatest amount of nutrient uptake occurred during the last third of the growing season, and followed the order of $\mathrm{K}>\mathrm{N}>\mathrm{Ca}>\mathrm{P}>\mathrm{Mg}$. These results agree with those of Lorenz and Maynard (8).

Factorial analysis indicated that $\mathrm{P}, \mathrm{K}, \mathrm{Ca}$ and $\mathrm{Mg}$ concentrations in the soil samples, and $\mathrm{pH}$ and $\mathrm{EC}$ at different positions with respect to dripper location, were not statistically different at the $5 \%$ level. P concentrations were higher directly under the dripper. $\mathrm{K}$ concentrations decreased with depth because peppers were able to extract $\mathrm{K}$ at $15-45$ $\mathrm{cm}$ depth because $60 \%$ of the roots were in this zone. Ca concentrations at planting and at last harvest were not significantly different, possibly because of low uptake of Ca by the plants. $\mathrm{Mg}$ concentrations at locations away from the drippers increased with crop season though the differences were not significant. The $\mathrm{pH}$ varied from $7.5-7.7$ at different locations and during the crop season. The electrical conductivity values decreased with depth at all locations away from the dripper and were in the range of $0.1-0.3 \mathrm{mmhos}$ per $\mathrm{cm}$. These results are in agreement with those of Goyal et al. (4).

\section{RESUMEN}

Se estableció en el Centro de Investigación y Desarrollo Agrícola de Fortuna, Juana Díaz, localizado en la costa semiárida del sur de Puerto Rico, un experimento para estudiar la extracción de nutrimentos (N, P, K, $\mathrm{Ca}$ y $\mathrm{Mg}$ ) por el pimiento (cv. Cubanelle) y el movimiento de solutos en relación a la posición del gotero. Se tomaron muestras del suelo a los 9 , 64 y 118 dias después del trasplante en varias posiciones con respecto a los goteros y se analizaron para $\mathrm{pH}, \mathrm{CE}, \mathrm{P}, \mathrm{K}, \mathrm{Ca}$ y $\mathrm{Mg}$. Todos los fertilizantes se aplicaron a través del sistema de riego por goteo. Los analisis factoriales no indicaron diferencias estadísticas en el movimiento de solutos a diferentes posiciones. Se usaron curvas de Mitscherlich para describir la relación entre nutrimentos contra días después del trasplante. La mayor extracción de nutrimentos ocurrió durante la última (tercera) parte del ciclo de vida del cultivo y siguió el orden de K, N, Ca, P, Mg.

\section{LITERATURE CITED}

1. Bar-Yosef, B, and Sheikhoslan, M. R., 1976. Distribution of water and ions in soils irrigated and fertilized from trickle source, Soil Sci. Soc. Am. J. 40: 575-81.

2. Black, C. A., 1965. Methods of Soil Analysis. II. Agronomy monograph No. 9, Am. Soc. Agron., Madison, WI.

3. Goldberg, D., Gornat, B. and Bar, B. 1971. The distribution of roots, water, and minerals as a result of trickle irrigation. J. Am. Soc. Hort. Sci. 96: 645-48. 
4. Goyal, M. R., Snyder, V. A., and Rivera, L. E., 1983. Solute movement in a tomato field under drip irrigation, J. Agric. Univ. P.R. 67 (4): 486-93.

5. Kafkafi, U. and Bar-Yosef, B. 1980. Trickle irrigation and fertilization of tomatoes in highly calcareous soils, Agron. J., 72: 873-97.

6. Keng, J. C. W., 1978. Water and nutrient management with drip irrigation in highly weathered soils of the tropics, Ph.D. dissertation, Cornell Univ.

7. — Scott, T. W., and Lugo-López, M. A., 1981. Fertilizer for sweet pepper under irrigation in an oxisol in northwestern Puerto Rico, J. Agric. Univ. P. R. 65 (2): 12328.

8. Lorenz, O. A. and Maynard, N., 1980. Knott's Handbook for Vegetable Growers, John Wiley \& Sons, 2nd ed. Page 390.

9. Perkin, E., 1973. Analytical Methods for Atomic Absorption Spectrophotometry, Norwalk, Conn., USA.

10. Phene, C. J., 1974. Subsurface irrigation in the humid southeastern coastal plains. In: Proceedings of Symposium on Water Resources-Utilization and Conservation in the Southeastern Environment held at Ft. Valley, GA. pages 267-303.

11. _ 1976. Management of seed-beds with trickle irrigation, The Flue Cured Tobacco Farmer, pages 8-11.

12. - and Beale, O. W., 1976. High frequency irrigation for water nutrient management in humid regions, Soil Sci. Soc. Am. J. 40:430-36.

13. — and Sanders D. C., 1976. High frequency trickle irrigation and row spacing effects on yield and quality of potatoes, Agron. J. 68: 602-07.

14. Rauschkolb, R. S., Rolston, D. E., Miller, R. J., Carlton, A. B., and Burau, R. G., 1976. Phosphorous fertilization with drip irrigation, Soil Sci. Soc. Am. J. 40: 68-72.

15. Rolston, D. E. and Broadbent, F. E., 1977. Field measurement of denitrification. EOA600/2-77233, US Environmental Protection Agency, Ada-OK.

16. Uriu, K., Carlson, R. M. and Henderson, D. W., 1977. Application of potassium fertilizer to prunes through a drip irrigation system. Seventh Int. Agr. Plastics Congress, San Diego, Calif., P. 211-14. 